\title{
Can we make Chitosan by Enzymatic Deacetylation of Chitin?
}

\author{
Rianne A. G. Harmsen, Tina R. Tuveng ${ }^{\mathbb{D}}$, Simen G. Antonsen ${ }^{\mathbb{D}}$, Vincent G. H. Eijsink \\ and Morten Sørlie *(D)
}

Department of Chemistry, Biotechnology and Food Science, Norwegian University of Life Sciences, PO 5003, N-1432 Ås, Norway; rianne.harmsen83@gmail.com (R.A.G.H.); tina.tuveng@nmbu.no (T.R.T.); simen.antonsen@nmbu.no (S.G.A.); vincent.eijsink@nmbu.no (V.G.H.E.)

* Correspondence: morten.sorlie@nmbu.no

Received: 27 September 2019; Accepted: 23 October 2019; Published: 26 October 2019

\begin{abstract}
Chitin, an insoluble linear polymer of $\beta-1,4-N$-acetyl-D-glucosamine (GlcNAc; A), can be converted to chitosan, a soluble heteropolymer of GlcNAc and D-glucosamine (GlcN; D) residues, by partial deacetylation. In nature, deacetylation of chitin is catalyzed by enzymes called chitin deacetylases (CDA) and it has been proposed that CDAs could be used to produce chitosan. In this work, we show that CDAs can remove up to approximately $10 \%$ of $\mathrm{N}$-acetyl groups from two different ( $\alpha$ and $\beta$ ) chitin nanofibers, but cannot produce chitosan.
\end{abstract}

Keywords: chitin; chitosan; chitin deacetylase; nuclear magnetic resonance

\section{Introduction}

Chitin, the second most abundant biopolymer in nature, is a crystalline linear polysaccharide containing $\beta-1,4$ linked $N$-acetyl glucosamine (GlcNAc, A) residues. It is a common structural component in cell walls of yeast and fungi and in the exoskeletons of insects, crustaceans, and parasitic nematodes [1,2]. Alpha-chitin is the most common chitin form. It contains GlcNAc chains in an antiparallel orientation [3], and it is found in insects, crustaceans, fungi, and yeast. Beta-chitin is derived from squid pens and exists in parallel GlcNAc chains [1,4]. In $\gamma$-chitin, the rarest crystalline form of chitin found in insects and in the stomach of the Loligo squid, two GlcNAc chains are oriented in one direction and the third runs in the opposite direction $[3,5]$. The individual chitin chains are held together by hydrogen bonds [3].

Partial deacetylation of chitin yields chitosan, a heteropolymer of (1-4)-linked (GlcNAc) and glucosamine (GlcN, D) units with the GlcN units randomly distributed along the polymer chain [6]. The name chitosan refers to a continuum of soluble polymeric chitin derivatives that can be described and classified according to several characteristics where the degree of polymerization (DP) and the fraction of $N$-acetylated residues $\left(\mathrm{F}_{\mathrm{A}}\right)$ are the most important. In weak acidic media, the GlcN units are charged, making chitosan, unlike chitin, water-soluble [1,7]. Solubility in weak aqueous media requires the $\mathrm{F}_{\mathrm{A}}$ to be below approximately 0.65 [8]. Due to its non-toxicity, biodegradability, and biocompatibility, combined with interesting biological and physicochemical properties, chitosan has various applications in agriculture, industry, medicine, water treatment, and biotechnology [1,7]. The most common method for conversion of chitin to chitosan is usually done by demineralization and deproteination of chitin-rich biomass at high temperature using aqueous $\mathrm{NaOH}$ as a base [9]. This is a relatively uncontrolled process that generates basic wastewater that may lead to environmental pollution [10].

In nature, enzymes called chitin deacetylases (CDAs) that belong to the family 4 of carbohydrate esterases (CE4), according to the CAZy classification system (www.cazy.org) [11], catalyze the removal 
of $\mathrm{N}$-acetyl groups from chitin. This esterase family comprises enzymes that de- $\mathrm{N}$ - or de-O-acetylate chitin, acetyl xylan and peptidoglycan. Ever since the discovery of the characterization of these enzymes, it has been speculated that CDAs could be used to convert chitin into chitosan, in what would be an environmentally-friendly and potentially cost-efficient approach. While seemingly attractive, from a theoretical point of view, it may not seem very likely that CDAs would be able to solubilize chitin (further discussed below). In this study, we have investigated the possibility of several CDAs to solubilize chitin, focusing on a chitin deacetylase from Vibrio cholerae (VcCDA) as a deacetylation catalyst [12]. As a substrate, we assessed both $\alpha$ - and $\beta$-chitin nanofibers with a high surface to volume ratio, which presumably would make these fibers particularly suited for enzymatic deacetylation.

\section{Results and Discussion}

Initially, three enzymes with known chitin-deacetylating activity, VcCDA from Vibrio cholera [12,13], AnCDA9 from Aspergillus nidulans [14], and SpPgdA from Streptococcus pneumoniae [15] were assessed for their ability to deacetylate chitin nanofibers using the methods described below. Incubation with chitin nanofibers for $48 \mathrm{~h}$ displayed an ability of the deacetylases to remove 3-6\% of the $\mathrm{N}$-acetyl groups (results not shown). For further investigation, we chose to focus on $V c C D A$ since this appeared to most efficient of the three enzymes.

Prior to in-depth studies with $V c \mathrm{CDA}$, untreated $\alpha$ - and $\beta$-chitin nanofibers were subjected to ${ }^{1} \mathrm{H}$ NMR to determine the $\mathrm{F}_{\mathrm{A}}$ of the starting materials according to Einbu and Vårum (Figure 1) [16]. The $\mathrm{F}_{\mathrm{A}}$ was calculated using Equation (1):

$$
\mathrm{F}_{\mathrm{A}}=\frac{\left(\mathrm{I}_{\alpha \mathrm{H} 1 \mathrm{~A}}+\mathrm{I}_{\beta \mathrm{H} 1 \mathrm{~A}+\mathrm{H} 1 \mathrm{D}}+\mathrm{I}_{\mathrm{H} 1 \mathrm{~A}}\right)-\mathrm{I}_{\mathrm{H} 2 \mathrm{D}}}{\left(\mathrm{I}_{\alpha \mathrm{H} 1 \mathrm{~A}}+\mathrm{I}_{\beta \mathrm{H} 1 \mathrm{~A}+\mathrm{H} 1 \mathrm{D}}+\mathrm{I}_{\mathrm{H} 1 \mathrm{~A}}\right)},
$$

where $\mathrm{I}_{\alpha \mathrm{H} 1 \mathrm{~A}}$ represent the integral of the $\mathrm{H}-1$ protons of the $\alpha$-anomer at the reducing end of GlcNAc residues, $\mathrm{I}_{\beta \mathrm{H} 1 \mathrm{~A}+\mathrm{H} 1 \mathrm{D}}$ represents the integral of the $\mathrm{H}-1$ protons of the $\beta$-anomer at the reducing end of GlcNAc and GlcN residues, respectively, $\mathrm{I}_{\mathrm{H} 1 \mathrm{~A}}$ represents the integral of $\mathrm{H}-1$ protons of GlcNAc residues within the polymer chain, and $\mathrm{I}_{\mathrm{H} 2 \mathrm{D}}$ represents the integral of $\mathrm{H}-2$ protons of GlcN residues with the polymer chain [16]. By subtracting the integral from $\mathrm{H}-2$ from $\mathrm{GlcN}$ units $\left(\mathrm{I}_{\mathrm{H} 2 \mathrm{D}}\right)$ from the integral representing all $\mathrm{H}-1$ protons $\left(\mathrm{I}_{\alpha \mathrm{H} 1 \mathrm{~A}}+\mathrm{I}_{\beta \mathrm{H} 1 \mathrm{~A}+\mathrm{H} 1 \mathrm{D}}+\mathrm{I}_{\mathrm{H} 1 \mathrm{~A}}\right)$, the integral representing only acetylated unit is obtained. Thus, Equation (1) implies that the $\mathrm{F}_{\mathrm{A}}$ is determined by dividing the integral of only acetylated units by the integral of all H-1 protons [16]. As expected for polymeric chitin, no significant peak was observed for the $\alpha$-conformation at the $\mathrm{C} 1$. This approach yielded $\mathrm{F}_{\mathrm{A}}$ values of 0.950 and 0.895 for $\alpha$ - and $\beta$-chitin, respectively (Figure 1). This implies that the chitin nanofibers contain an inherent small fraction of deacetylated units, in accordance with previous observations [16]. The fraction of acetylated units $\left(\mathrm{F}_{\mathrm{A}}\right)$ in both $\alpha$ - and $\beta$-chitin nanofibers after incubation with $V c C D A$ at $37^{\circ} \mathrm{C}$ was determined at different time points (Figure 2). After 10 days, the $\mathrm{F}_{\mathrm{A}}$ values reached minima of 0.85 , for $\alpha$-chitin, and 0.83 for $\beta$-chitin as observed as a stopped decline in $\mathrm{F}_{\mathrm{A}}$ values with respect to time (depicted in Figure 2). 

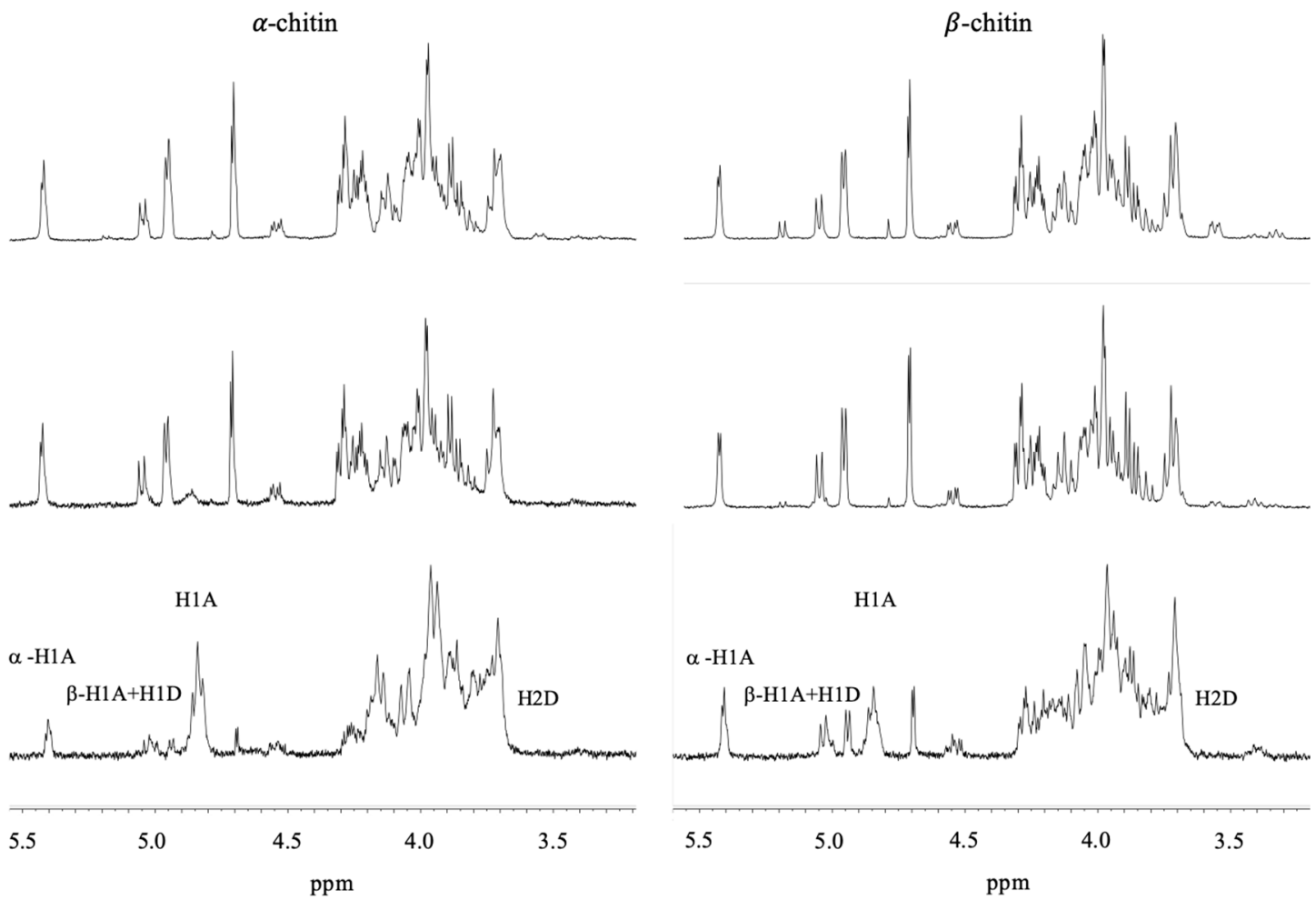

Figure 1. ${ }^{1} \mathrm{H}$ NMR spectrum of untreated $\alpha$-chitin (bottom left, $\mathrm{F}_{\mathrm{A}}=0.950$ ) and $\beta$-chitin (bottom right, $\left.\mathrm{F}_{\mathrm{A}}=0.895\right)$ nanofibers before addition of $V c C D A$ and after $24 \mathrm{~h}\left(\alpha\right.$-chitin middle left, $\left.\mathrm{F}_{\mathrm{A}}=0.945\right)$ and ( $\beta$-chitin middle right, $\left.\mathrm{F}_{\mathrm{A}}=0.873\right)$, and $48 \mathrm{~h}\left(\alpha\right.$-chitin middle left, $\left.\mathrm{F}_{\mathrm{A}}=0.898\right)$ and $(\beta$-chitin middle right, $\mathrm{F}_{\mathrm{A}}=0.852$ ) of incubation with $V c \mathrm{CDA}$. The peaks of $\beta \mathrm{H} 1$ and $\mathrm{H} 1 \mathrm{D}$ come at ppm of 5.05 and 5.07, respectively, H1A comes at ppm 4.91, and H2D comes at ppm 3.44 [16].

To ensure that the decrease in the rate of deacetylation was not due to the inactivation of $V c \mathrm{CDA}$. A new batch of the enzyme was added after $240 \mathrm{~h}$, thus doubling the total amount of added enzyme from $0.5 \mu \mathrm{M}$ to $1.0 \mu \mathrm{M}$ and incubated for another $24 \mathrm{~h}$. This did not lead to a significant further increase in deacetylation ( $\mathrm{F}_{\mathrm{A}}$ of 0.857 vs. 0.854 for $\alpha$-chitin and 0.831 vs. 0.824 for $\beta$-chitin, respectively), indicating that essentially no more acetyl groups are available as a substrate for $V c C D A$.

In another control experiment, soluble $N, N$-diacetyl chitobiose (to a final concentration of $1 \mathrm{mM}$ ) was added to the reaction mixtures after $120 \mathrm{~h}$ of incubation with the chitin substrates and was allowed to incubate for $24 \mathrm{~h}$ with the chitobiose substrate. VcCDA catalyzes the hydrolysis of the $\mathrm{N}$-acetyl groups attached to the penultimate GlcNAc residue from the non-reducing end [13], and mass spectrometry analysis showed that $24 \mathrm{~h}$ after its addition, all chitobiose had lost an $\mathrm{N}$-acetyl group (Figure S1). It is thus clear that the stagnation in the deacetylation is not due to enzyme deactivation. The binding of $V c C D A$ to $\beta$-chitin nanofibers was also assessed to see if the low degree of maximum deacetylation could be due to strong, perhaps unproductive binding of $V c C D A$ to the substrate, which could make the enzyme incapable of performing catalysis. The plot of bound protein versus free protein was fitted to Equation (2) yielding a $\mathrm{K}_{\mathrm{d}}$ of $5 \pm 2 \mu \mathrm{M}$ and a $\mathrm{B}_{\max }$ of $8.4 \mu \mathrm{M}$, in the fit, which corresponds to $0.1 \mu \mathrm{mol} / \mathrm{gram}$ chitin fiber (Figure 3).

$$
\mathrm{P}_{\text {bound }}=\frac{\mathrm{B}_{\max } \times\left[\mathrm{P}_{\text {free }}\right]}{\mathrm{K}_{\mathrm{d}}+\left[\mathrm{P}_{\text {free }}\right]},
$$

This suggests that, at conditions used with an initial concentration of $\mathrm{VcCDA}$ of $0.5 \mu \mathrm{M}, 0.18 \mu \mathrm{M}$ will at any time be free in solution and $0.32 \mu \mathrm{M}$ associated with the substrate. It is thus not likely that the non-productive binding of $V c C D A$ led to reduced deacetylation. 
a)

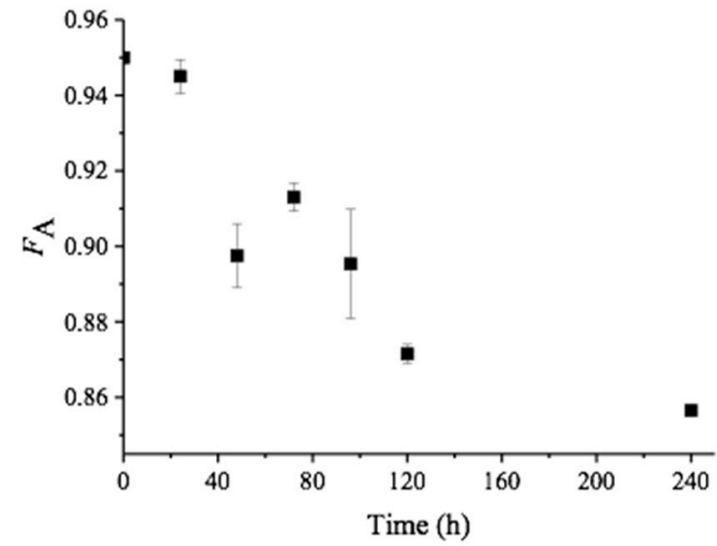

b)|

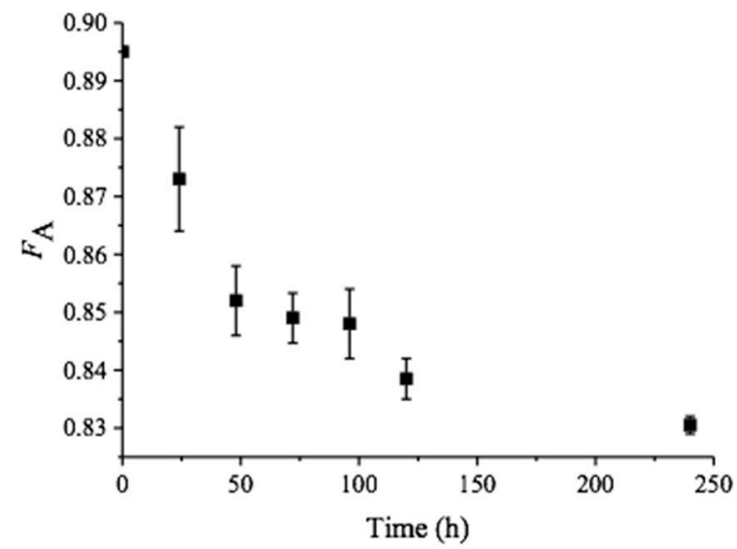

Figure 2. Change in $\mathrm{F}_{\mathrm{A}}$ over time upon incubation of $\alpha$-chitin (a) or $\beta$-chitin (b) with $V c \mathrm{CDA}$ at $\mathrm{pH} 8.0$ and $\mathrm{t}=37^{\circ} \mathrm{C}$, as determined by ${ }^{1} \mathrm{H}$ NMR spectroscopy. The points show average values derived from three independent experiments with standard deviations. Note that starting $\mathrm{F}_{\mathrm{A}}$ values were 0.950 and 0.895 for $\alpha$ - and $\beta$-chitin, respectively.

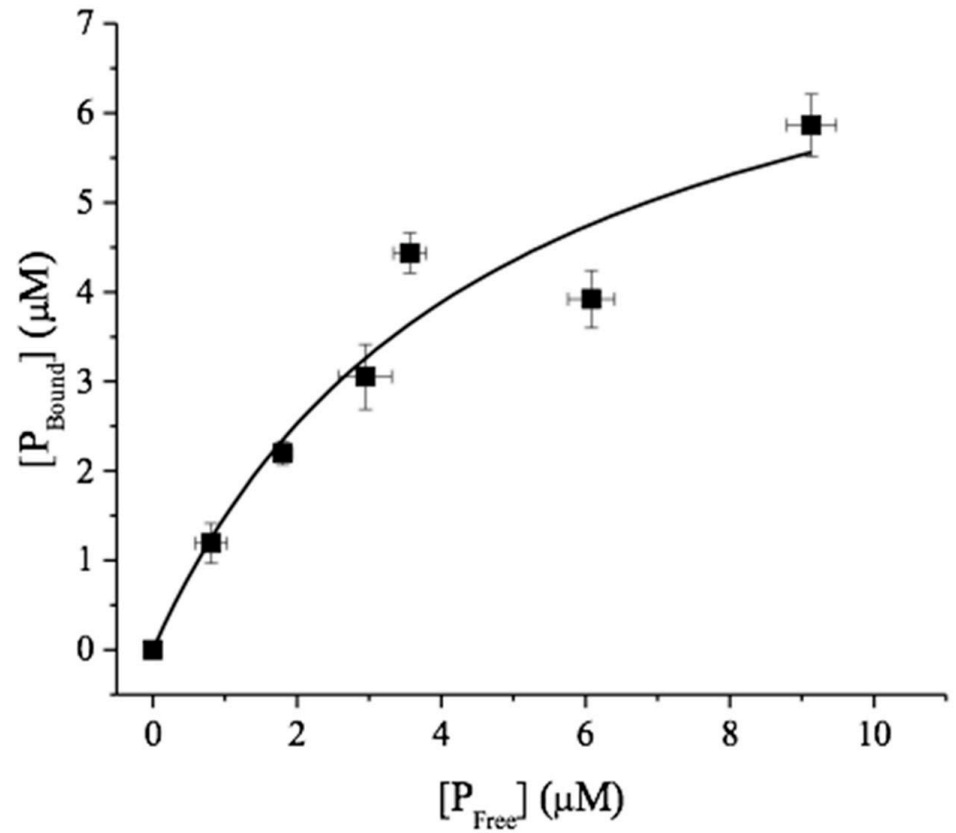

Figure 3. Equilibrium isotherm for the adsorption of $V c C D A$ to $\beta$-chitin nanofibers at $\mathrm{pH} 8.0$ and $\mathrm{t}=37^{\circ} \mathrm{C}$. 


\section{Materials and Methods}

\subsection{Materials}

Both $\alpha$ - and $\beta$-chitin nanofibers, derived from crab shells, were kindly donated by S. Ifuku, Department of Chemistry and Biotechnology, Tottori University Japan (Tottori City, Japan) [17,18]. Dialyzed chitin nanofibers $\mathrm{DH}_{2} \mathrm{O}$ were lyophilized using a Christ Alpha 2-4 LD plus freeze dryer. N,N-Diacetyl chitobiose was purchased from Megazyme (Wicklow, Ireland). All further chemicals and solvents were purchased from Sigma-Aldrich (St. Louis, MO, USA) and used without further purification.

\subsection{Production of AnCDA9, SpPgdA, and VcCDA}

AnCDA9 from Aspergillus nidulans was produced in Escherichia coli and purified as described previously [14]. SpPgdA from Streptococcus pneumoniae in E. coli and purified as described previously [15].

The gene encoding VcCDA (accession code AAF94439) was ordered from Gen-Script (Piscataway, NJ, USA). The gene, without the nucleotides encoding the signal peptide, was amplified by PCR using a forward (5' -TTAAGAAGGAGATATACTATGAATAGCACCCCGAAAGGCA C-3') and reverse (5' -AATGGTGGTGATGATGGTGCGCCAGCGCGGTGAACAGGGTA-3') primer (Eurofins, Ebersberg, Germany). The underlined nucleotides represent over-hang sequences. The amplified PCR product was subsequently cloned into the pNIC-CH vector [19] utilizing ligation-independent cloning (LIC) [20]. As a result of this cloning strategy, the N-terminus of the (signal peptide-free) protein was extended with methionine on the N-terminus, while a seven residue His-tag (AHHHHHH) was added at the C-terminus. The pNIC-CH vector containing the $V c C D A$ gene sequence was then transformed into chemically competent XL1-Blue cells (Agilent, CA, USA) by heat shock. The host strain was allowed to proliferate in Super Optimal broth with catabolite repression (SOC) for 60 min prior to plating on lysogenic broth (LB) agar containing $50 \mu \mathrm{g} / \mathrm{mL}$ kanamycin and 5\% sucrose. After incubation overnight at $37^{\circ} \mathrm{C}$, single transformant colonies were inoculated in liquid LB containing $50 \mu \mathrm{g} / \mathrm{mL}$ kanamycin and incubated overnight at $37^{\circ} \mathrm{C}$. The plasmid was isolated from transformants using a NucleoSpin Plasmid kit (Macherey-Nagel), and the gene sequence of $V c C D A$ was verified by Sanger sequencing (GATC, Konstanz, Germany). The isolated plasmid was subsequently transformed by heat shock into chemically competent OneShot BL-21 Star ${ }^{\mathrm{TM}}$ (DE3) E. coli cells (Invitrogen) and grown in SOC media as described above, before plating on LB agar containing $50 \mu \mathrm{g} / \mathrm{mL}$ kanamycin and overnight incubation

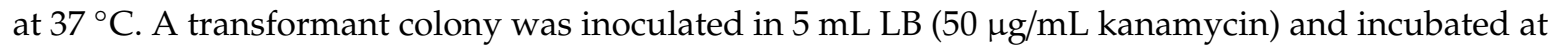
$37^{\circ} \mathrm{C}$ overnight. The pre-culture was then grown in $0.5 \mathrm{~L}$ Terrific Brothcontaining $50 \mu \mathrm{g} / \mathrm{mL}$ kanamycin using a Harbinger system (Harbinger Biotechnology and Engineering, Markham, Canada) at $21^{\circ} \mathrm{C}$. After $24 \mathrm{~h}$, the culture was induced with isopropyl- $\beta$-D-thiogalactopyranoside (final concentration $0.2 \mathrm{mM})$, followed by incubation at $21^{\circ} \mathrm{C}$ for $24 \mathrm{~h}$. The cells were harvested by centrifugation $(8000 \mathrm{rpm}$, $20 \mathrm{~min}$ at $4^{\circ} \mathrm{C}$ ) and the pellet resuspended in $30 \mathrm{~mL} 20 \mathrm{mM}$ Tris- $\mathrm{HCl} \mathrm{pH} \mathrm{8,} 20 \mathrm{mM}$ imidazole, $500 \mathrm{mM}$ $\mathrm{NaCl}$ before the cells were lysed using a Vibra-cell sonicator (Sonics and Materials Inc., Newtown, CT, USA) with $5 \mathrm{~s}$ on/off pulses for $4 \mathrm{~min}$ at $28 \%$ amplitude while kept on ice. The cell debris was removed by centrifugation at $12,000 \mathrm{rpm}$ for $15 \mathrm{~min}$ and the cell-free protein extract was filtrated using a $0.45 \mu \mathrm{m}$ syringe filter (Sarstedt, Nümbrecht, Germany). Proteins were purified from the resulting cell-free extract using a column packed with Ni-NTA Agarose (Qiagen, Venlo, The Netherlands, $1.5 \mathrm{~cm}$ in diameter, $5 \mathrm{~mL}$ stationary phase in total). The column was pre-equilibrated in a buffer containing $20 \mathrm{mM}$ Tris- $\mathrm{HCl}, 20 \mathrm{mM}$ imidazole, and $500 \mathrm{mM} \mathrm{NaCl}, \mathrm{pH} 8.0$, before the cell extracts

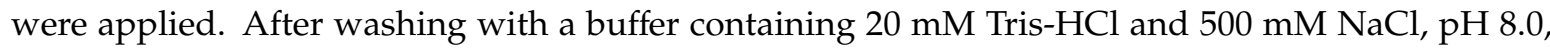
the enzyme was eluted with a buffer containing $20 \mathrm{mM}$ Tris- $\mathrm{HCl}, 250 \mathrm{mM}$ imidazole, and $500 \mathrm{mM}$ $\mathrm{NaCl}, \mathrm{pH}$ 8.0. A flow rate of $2.5 \mathrm{~mL} / \mathrm{min}$ was used at all times. Enzyme purity of all CDAs was verified by SDS-PAGE (Supplementary Figure S1) and fractions containing purified enzymes were concentrated and transferred to $20 \mathrm{mM}$ potassium phosphate buffer $\mathrm{pH} 6.0$ by centrifugal ultrafiltration (Macrosep 
Advance Centrifugal Device, 10 kDa cutoff, Pall Corporation, Port Washington, NY, USA). Protein concentration was determined by using the Bradford Protein Assay from Bio-Rad (Hercules, CA, USA).

After purification, the enzymes were checked to have similar activity as reported values [13-15] by initial acetate release from $N, N$-diacetyl chitobiose $(1 \mathrm{mM})$ measured by IC using a Dionex ICS3000 system with suppressed conductivity detection as described by Liu et al. [14].

\subsection{Enzymatic Deacetylation of Chitin Nanofibers}

Both $\alpha$ - and $\beta$-chitin nanofibers $(5 \mathrm{mg} / \mathrm{mL})$ were incubated with CDA $(0.5 \mu \mathrm{M})$ in Tris- $\mathrm{HCl}(25 \mathrm{mM}$, $\mathrm{pH} 8.0)$ and $\mathrm{CoCl}_{2}(0.1 \mathrm{mM})$ at $37^{\circ} \mathrm{C}$, with shaking at $800 \mathrm{rpm}$. Samples $(13 \mathrm{~mL})$ were taken at different time points and enzyme activity was immediately quenched by adding an equal volume of acetonitrile. After removal of the organic solvent under reduced pressure, the materials were dialyzed to $\mathrm{H}_{2} \mathrm{O}$, using Spectra/Por 6 dialysis membranes with a cutoff of $100 \mathrm{Da}$, followed by lyophilization using a Christ Alpha 2-4 LD plus freeze dryer, which rendered the chitin fibers colorless solids. Three parallels of each sample were prepared for ${ }^{1} \mathrm{H}$ NMR analysis.

\section{4. ${ }^{1} H$ NMR of $\alpha$-and $\beta$-Chitin Nanofibers}

${ }^{1} \mathrm{H}$ NMR sample preparation was conducted as described by Einbu and Vårum [16]. The lyophilized chitin nanofiber samples were first wetted with $100 \mu \mathrm{L} 1 \% \mathrm{DCl}$ in $\mathrm{D}_{2} \mathrm{O}(99.9$ atom \% D, contains $0.05 \mathrm{wt} \%$ TMS as internal standard) followed by dissolving in $700 \mu \mathrm{L} 37 \% \mathrm{DCl}$. ${ }^{1} \mathrm{H} \mathrm{NMR}$ spectra were recorded at $25{ }^{\circ} \mathrm{C}$ with 64 scans using a Bruker AscendTM $400 \mathrm{MHz}$ spectrometer. The chemical shifts are reported in parts per million $(\mathrm{ppm})$ relative to TMS.

The fraction of acetylated units $\left(\mathrm{F}_{\mathrm{A}}\right)$ was calculated according to Einbu and Vårum [16] using the integrals of $\mathrm{H} 1$ - and $\mathrm{H} 2$ protons of GlcNAc and GlcN residues as described in the text.

\subsection{Enzyme Activity Test}

Remaining chitin deacetylase activity after five days of incubation with chitin nanofibers was measured by adding of $N, N$-diacetyl chitobiose to the reaction mixture to a final concentration of $1 \mathrm{mM}$. After $24 \mathrm{~h}$, deacetylation products were analyzed by MALDI-TOF, as described by Cederkvist et al. [21].

\subsection{Binding Assay}

Enzyme binding to $\beta$-chitin nanofibers was assessed as described by Zakariassen et al. [22]. $V c C D A$ was diluted to various concentrations $(0-20 \mu \mathrm{M})$ in Tris- $\mathrm{HCl}(25 \mathrm{mM}, \mathrm{pH} 8.0)$ and $0.1 \mathrm{mM}$ $\mathrm{CoCl}_{2}$. The $\mathrm{A}_{280}$ of these solutions was measured, and a standard curve was created. The reaction volume was $1.0 \mathrm{~mL}$, the concentration of $\beta$-chitin WAS $5 \mathrm{mg} / \mathrm{mL}$, and the $V c C D A$ concentration in the mixtures was $0,2,4,6,8,10$, and $16 \mu \mathrm{M}$, respectively. The mixtures were incubated at $37^{\circ} \mathrm{C}$ and $300 \mathrm{rpm}$. After $2 \mathrm{~h}$, the $\beta$-chitin nanofibers were spun down for $20 \mathrm{~min}$ at 13,000 rpm, and the $\mathrm{A}_{280}$ values of the supernatants were measured. The bound and free protein concentrations $\left(\left[\mathrm{P}_{\text {bound }}\right],\left[\mathrm{P}_{\text {free }}\right]\right)$ were calculated from the standard curve. All assays were performed in triplicate. The equilibrium dissociation constant $\mathrm{K}_{\mathrm{d}}(\mu \mathrm{M})$ and binding capacity $\mathrm{B}_{\max }(\mu \mathrm{mol} / \mathrm{g})$ were determined by fitting the binding isotherms to the following equation: $\left[\mathrm{P}_{\text {bound }}\right]=\mathrm{B}_{\max } \times\left[\mathrm{P}_{\text {free }}\right] /\left[\mathrm{K}_{\mathrm{d}}+\mathrm{P}_{\text {free }}\right]$ by non-linear regression using Origin v7.0 software (OriginLab Corporation, Northampton, MA, USA).

\section{Conclusions}

Polymers of chitin are synthesized as crystalline fibrils that are hundreds to thousands of monomer units long [23]. Calculations show that the removal of a GlcNAc dimer from chitin crystal comes with a thermodynamic penalty of $8 \mathrm{kcal} / \mathrm{mol}$ [24]. Our results demonstrate that a CDA is able to reduce the degree of acetylation for two different types of crystalline chitin ( $\alpha$ and $\beta$ ), but only by up to approximately $10 \%$. This prompts us to speculate that the enzymatic action of a CDA is not able to overcome the thermodynamic penalty of removing single polymer chains from the 
crystal to access all available $N$-acetyl groups. In nature, chitin is degraded by glycoside hydrolases (GH) and lytic polysaccharide monooxygenases (LPMO) [25,26]. GHs overcome the thermodynamic penalty of decrystallization by strong binding to a single polysaccharide chain through several surface-exposed aromatic amino acids and by this pulling the chain from the crystal into the active site of the enzymes $[27,28]$. Moreover, the binding affinity of GHs towards the substrate increases with an increasing chain length of the substrate $[29,30]$. Typical binding free energy of a chitin active GH on six GlcNAc residues is $-9 \mathrm{kcal} / \mathrm{mol}\left(K_{\mathrm{d}}=0.2 \mu \mathrm{M}\right)$ [28]. LPMOs achieve decrystallization by activating an oxygen species on its copper-active site that is calculated to be strong enough, oxidize a C-H bond of $110 \mathrm{kcal} / \mathrm{mol}$ [31]. In contrast, we observe that $V c C D A$ binding free energy to $\beta$-chitin of $-7.5 \mathrm{kcal} / \mathrm{mol}$ $\left(K_{\mathrm{d}}=5 \mu \mathrm{M}\right)$. Such a relative weak binding affinity is also confirmed from obtained Michaelis-Menten constants from various kinetic analyses. $S p$ PgdA is reported to have a $K_{\mathrm{m}}$ of $3.8 \mathrm{mM}$, which translates to a binding free energy of $-3.4 \mathrm{kcal} / \mathrm{mol}$, with (GlcNAc) $)_{3}$ as the substrate, while AnCDA9 has a $K_{\mathrm{m}}$ of $72 \mu \mathrm{M}$, which translates to a binding free energy of $-5.9 \mathrm{kcal} / \mathrm{mol}$, with (GlcNAc) 5 as the substrate [14,15].

Even though it is not likely that the use of a CDA alone is sufficient to produce chitosan directly from chitin, its action on crystalline chitin may be useful. CDA action introduced $\mathrm{NH}_{2}$-group on the fibril surface, which can serve as a starting point for surface modifications, i.e., through "click chemistry", thus offering an opportunity for creating new materials [32,33].

Supplementary Materials: The following are available online, Figure S1: MALDI-TOF-MS spectra of $N, N$-diacetyl chitobiose after incubation with $V c C D A$ for $24 \mathrm{~h}$. Figure S2: Table S1: SDS PAGE GEL analysis of $V c C D A, S p P g d A$, and AnCDA9.

Author Contributions: Conceptualization: R.A.G.H., V.G.H.E., and M.S. Formal analysis: R.A.G.H., S.G.A., T.R.T., and M.S. Investigation: R.A.G.H., S.G.A., T.R.T., V.G.H.E., and M.S. Supervision: V.G.H.E. and M.S. Writing-original draft: R.A.G.H. Writing-review and editing: V.G.H.E. and M.S

Funding: This work was supported by Grant 221576 from the Research Council of Norway.

Acknowledgments: We thank Shinsuke Ifuku (Department of Chemistry and Biotechnology, Tottori University) for providing us with $\alpha$ - and $\beta$-chitin nanofibers, and Anne Tøndervik (SINTEF Materials and Chemistry, Trondheim, Norway) for purified SpPgdA.

Conflicts of Interest: The authors declare no conflict of interest. The funders had no role in the design of the study; in the collection, analyses, or interpretation of data; in the writing of the manuscript, or in the decision to publish the results.

\section{References}

1. Aam, B.B.; Heggset, E.B.; Norberg, A.L.; Sørlie, M.; Vårum, K.M.; Eijsink, V.G.H. Production of chitooligosaccharides and their potential applications in medicine. Mar. Drugs 2010, 8, 1482-1517. [CrossRef] [PubMed]

2. Minke, R.; Blackwell, J. The structure of $\alpha$-chitin. J. Mol. Biol. 1978, 120, 167-181. [CrossRef]

3. Jang, M.-K.; Kong, B.-G.; Jeong, Y.-I.; Lee, C.H.; Nah, J.-W. Physicochemical characterization of $\alpha$-chitin, $\beta$-chitin, and $\gamma$-chitin separated from natural resources. J. Polym. Sci. Part A Polym. Chem. 2004, 42, 3423-3432. [CrossRef]

4. Muzzarelli, R.A.A. Chitins and chitosans as immunoadjuvants and non-allergenic drug carriers. Mar. Drugs 2010, 8, 292-312. [CrossRef] [PubMed]

5. Alvarez, F.J. The effect of chitin size, shape, source and purification method on immune recognition. Molecules 2014, 19, 4433-4451. [CrossRef]

6. Vårum, K.M.; Ottoy, M.H.; Smidsrød, O. Acid hydrolysis of chitosans. Carbohyd. Polym. 2001, 46, 89-98. [CrossRef]

7. Vårum, K.M.; Anthonsen, M.W.; Grasdalen, H.; Smidsrød, O. 13c-nmr. Studies of the acetylation sequences in partially n-deacetylated chitins (chitosans). Carbohydr. Res. 1991, 217, 19-27. [CrossRef]

8. Vårum, K.M.; Ottøy, M.H.; Smidsrød, O. Water-solubility of partially n-acetylated chitosans as a function of ph-effect of chemical-composition and depolymerization. Carbohydr. Polym. 1994, 25, 65-70. [CrossRef] 
9. Sannan, T.; Kurita, K.; Iwakura, Y. Studies on chitin: 2. Effect of deacetylation on solubility. Makromol. Chem. 1976, 177, 3589-3600. [CrossRef]

10. Cai, J.; Yang, J.; Du, Y.; Fan, L.; Qiu, Y.; Li, J.; Kennedy, J.F. Enzymatic preparation of chitosan from the waste aspergillus niger mycelium of citric acid production plant. Carbohydr. Polym. 2006, 64, 151-157. [CrossRef]

11. Lombard, V.; Ramulu, H.G.; Drula, E.; Coutinho, P.M.; Henrissat, B. The carbohydrate-active enzymes database (cazy) in 2013. Nucleic Acids Res. 2014, 42, D490-D495. [CrossRef] [PubMed]

12. Andrés, E.; Albesa-Jové, D.; Biarnés, X.; Moerschbacher, B.M.; Guerin, M.E.; Planas, A. Structural basis of chitin oligosaccharide deacetylation. Angew. Chem. Int. Ed. Engl. 2014, 53, 6882-6887. [CrossRef] [PubMed]

13. Li, X.B.; Wang, L.X.; Wang, X.S.; Roseman, S. The chitin catabolic cascade in the marine bacterium vibrio cholerae: Characterization of a unique chitin oligosaccharide deacetylase. Glycobiology 2007, 17, 1377-1387. [CrossRef] [PubMed]

14. Liu, Z.L.; Gay, L.M.; Tuveng, T.R.; Agger, J.W.; Westereng, B.; Mathiesen, G.; Horn, S.J.; Vaaje-Kolstad, G.; van Aalten, D.M.F.; Eijsink, V.G.H. Structure and function of a broadspecificity chitin deacetylase from aspergillus nidulans fgsc a4. Sci. Rep. 2017, 7, 12.

15. Blair, D.E.; Schüttelkopf, A.W.; MacRae, J.I.; van Aalten, D.M.F. Structure and metal-dependent mechanism of peptidoglycan deacetylase, a streptococcal virulence factor. Proc. Natl. Acad. Sci. USA 2005, 102, 15429-15434. [CrossRef] [PubMed]

16. Einbu, A.; Vårum, K.M. Characterization of chitin and its hydrolysis to glcnac and glcn. Biomacromolecules 2008, 9, 1870-1875. [CrossRef] [PubMed]

17. Ifuku, S.; Nogi, M.; Abe, K.; Yoshioka, M.; Morimoto, M.; Saimoto, H.; Yano, H. Preparation of chitin nanofibers with a uniform width as $\alpha$-chitin from crab shells. Biomacromolecules 2009, 10, 1584-1588. [CrossRef]

18. Ifuku, S.; Saimoto, H. Chitin nanofibers: Preparations, modifications, and applications. Nanoscale 2012, 4, 3308-3318. [CrossRef]

19. Savitsky, P.; Bray, J.; Cooper, C.D.O.; Marsden, B.D.; Mahajan, P.; Burgess-Brown, N.A.; Gileadi, O. High-throughput production of human proteins for crystallization: The sgc experience. J. Struct. Biol. 2010, 172, 3-13. [CrossRef]

20. Aslanidis, C.; de Jong, P.J. Ligation-independent cloning of pcr products (lic-pcr). Nucleic Acids Res. 1990, 18, 6069-6074. [CrossRef]

21. Cederkvist, F.H.; Parmer, M.P.; Vårum, K.M.; Eijsink, V.G.H.; Sørlie, M. Inhibition of a family 18 chitinase by chitooligosaccharides. Carbohyd. Polym. 2008, 74, 41-49. [CrossRef]

22. Zakariassen, H.; Klemetsen, L.; Sakuda, S.; Vaaje-Kolstad, G.; Vårum, K.M.; Sørlie, M.; Eijsink, V.G.H. Effect of enzyme processivity on the efficacy of a competitive chitinase inhibitor. Carbohyd. Polym. 2010, 82, 779-785. [CrossRef]

23. Synowiecki, J.; Al-Khateeb, N.A. Production, properties, and some new applications of chitin and its derivatives. Crit. Rev. Food Sci. 2003, 43, 145-171. [CrossRef] [PubMed]

24. Beckham, G.T.; Crowley, M.F. Examination of the $\alpha$-chitin structure and decrystallization thermodynamics at the nanoscale. J. Phys. Chem. B 2011, 115, 4516-4522. [CrossRef] [PubMed]

25. Monreal, J.; Reese, E.T. Chitinase of Serratia marcescens. Can. J. Microbiol. 1969, 15, 689-696. [CrossRef] [PubMed]

26. Chylenski, P.; Bissaro, B.; Sørlie, M.; Røhr, Å.K.; Várnai, A.; Horn, S.J.; Eijsink, V.G.H. Lytic polysaccharide monooxygenases in enzymatic processing of lignocellulosic biomass. ACS Catal. 2019, 9, 4970-4991. [CrossRef]

27. Beckham, G.T.; Ståhlberg, J.; Knott, B.C.; Himmel, M.E.; Crowley, M.F.; Sandgren, M.; Sørlie, M.; Payne, C.M. Towards a molecular-level theory of carbohydrate processivity in glycoside hydrolases. Curr. Opin. Struct. Biol. 2014, 27, 96-106. [CrossRef]

28. Hamre, A.G.; Jana, S.; Holen, M.M.; Mathiesen, G.; Väljamäe, P.; Payne, C.M.; Sørlie, M. Thermodynamic relationships with processivity in Serratia marcescens family 18 chitinases. J. Phys. Chem. B 2015, 119, 9601-9613. [CrossRef]

29. Norberg, A.L.; Karlsen, V.; Hoell, I.A.; Bakke, I.; Eijsink, V.G.H.; Sørlie, M. Determination of substrate binding energies in individual subsites of a family 18 chitinase. FEBS Lett. 2010, 584, 4581-4585. [CrossRef] 
30. Zolotnitsky, G.; Cogan, U.; Adir, N.; Solomon, V.; Shoham, G.; Shoham, Y. Mapping glycoside hydrolase substrate subsites by isothermal titration calorimetry. Proc. Natl. Acad. Sci. USA 2004, 101, 11275-11280. [CrossRef]

31. Hedegård, E.D.; Ryde, U. Targeting the reactive intermediate in polysaccharide monooxygenases. J. Biol. Inorg. Chem. 2017, 22, 1029-1037. [CrossRef] [PubMed]

32. Kritchenkov, A.S.; Skorik, Y.A. Click reactions in chitosan chemistry. Russ. Chem. Bull. 2017, 66, 769-781. [CrossRef]

33. Peng, P.; Cao, X.; Peng, F.; Bian, J.; Xu, F.; Sun, R. Binding cellulose and chitosan via click chemistry: Synthesis, characterization, and formation of some hollow tubes. Polym. Chem. 2012, 50, 5201-5210. [CrossRef]

Sample Availability: Samples of the compounds are not available from the authors.

(C) 2019 by the authors. Licensee MDPI, Basel, Switzerland. This article is an open access article distributed under the terms and conditions of the Creative Commons Attribution (CC BY) license (http://creativecommons.org/licenses/by/4.0/). 